\title{
Why Children Code-Switch? Sociolinguistic Factors
}

\author{
Patrick A. McCarthy \\ Département De Langues, Linguistique Et Traduction \\ Faculté Des Lettres \\ Université Laval \\ Québec
}

\begin{abstract}
This essay examines the general topic of child code-switching by primarily focusing on sociolinguistic variables that influence code-switching in a child's speech. Three factors were discussed. First, it is claimed that parents play an important role in their child's speech by the strategies that they choose to influence their child's language development. In addition, a child's proficiency in either of the two languages that he is using can also have an influence on whether a child code switches. Finally, it was also found that contextual situations could have a strong impact on a child's code switching.
\end{abstract}

\subsection{Research Problem and Rationale}

\subsection{The Research Problem}

Research pertaining to code-switching, both among children and adults, has been relatively neglected by linguists and sociolinguists alike. In fact, "there is a dearth of empirical research published that focuses on codeswitching" (Bokhorst-Heng \& Caleon, 2009, p. 237). This neglect is unfortunate because code-switching is an "intrinsic part of a bilingual child's language development" (Tokuhama-Espinosa, 2003, p. 133). Further, the increasing impact of globalization on communication makes research in the area of code-switching very relevant. Blom and Gumperz (1972) were among the first to describe code-switching as a "discourse strategy" rather than as an indicator of mental confusion. Yet, the lay public continues to doubt that code-switching is the outcome of specific linguistic rules and constraints, that it is neither haphazard, nor an indicator of linguistic incompetence (Grosjean, 2010; Milroy \& Muysken, 1995; Tokuhama-Espinosa, 2003). Both De Houwer (1995) and Lanza (1997) emphasize the paramount importance of studying how bilingual children learn to code-switch from a sociolinguistic viewpoint. This study responds to their emphasis. The focus of this present study will be to investigate the sociolinguistic factors that predispose, influence, or even compel a child to code-switch. The research question, then, is the following:Which sociolinguistic factors determine whether or to what extent a child code-switches?

\subsection{Importance of the essay}

Bokhorst-Heng and Caleon (2009) note that little empirical research has focused to date on code-switching, despite the fact that all over the world, code-switching exists in communities in which two or more languages are spoken. Gamal (2007, p. 234) insists, "more information is needed to ascertain why children code-switch". Boeschoten and Verhoeven (1987) and Cheng (2003) point out the lack of research relating to code-switching among children. Clearly, then, there is a need for a deeper understanding of the role that code switching plays within the realm of children and their world.

Tokuhama-Espinosa (2003) contends that monolinguals generally have difficulty understanding why a bilingual child might rapidly shift between two languages as he speaks. Further, monolinguals tend to interpret this phenomenon as "a sign of language weakness or inability to separate the languages" (Tokuhama-Espinosa, 2003, p.133). However, recent research (Grosjean, 2010) has shown that code-switching among bilinguals is not only normal, but it is also an integral part of how they communicate with each other on a daily basis. 


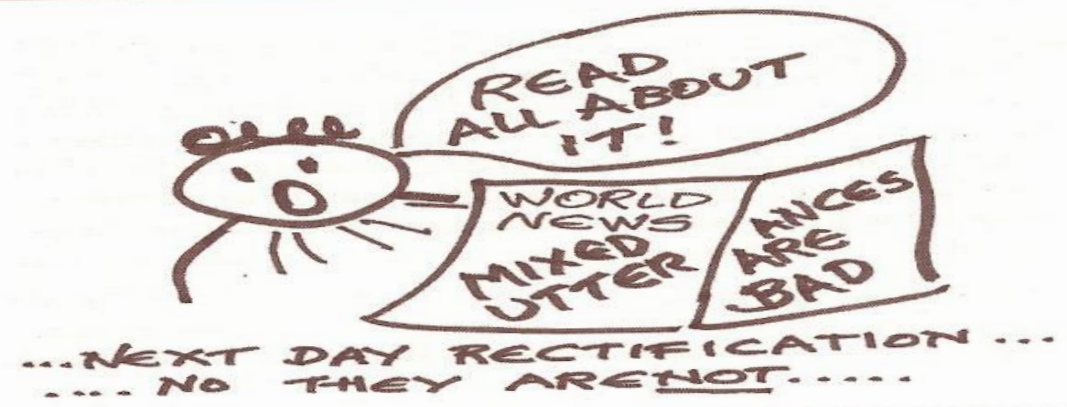

Figure 1.1 Adapted from de Houwer, 2009: 108

Moreover, it has been shown that very young children who are observed mixing their languages, do so as part of the initial period of normal language development (Tokuhama-Espinosa, 2003). Yet, de Houwer (1995) claims that still "very little is known about how the bilingual child is socialized into code-switching behaviour". The present review of the literature then, seeks to explain, from a primarily sociolinguistic perspective, what child code-switching actually entails.

Conducting such a review of the literature on such a research topic on children's code-switching has implications on the understanding of bilingualism, language development, and second language acquisition. It will also be of interest to language professionals and teachers who work with bilingual children. Parents and other childcare workers may also benefit from its findings especially if they are dealing with more than one language in their environment.

\subsection{Scope and Limitations}

The present review limits itself to descriptions of situational code-switching, conversational code-switching, and to thesocial, contextual, and pragmatic factors that underlie language choice on the part of the subjects. Moreover, it primarily focuses on bilingual first language children who have been exposed to two different languages since birth. Finally, the studies examined include participants who are children between the ages of two and twelve years old.

\subsection{Theoretical Framework}

\subsection{Definition of Terms}

As mentioned by Meisel (1994), given the terminological confusion that currently exists in this area of research, we shall next discuss some of the terms that are used in the literature on child code-switching.

\section{Bilingualism}

Bilingualism is probably the most important term to define at the onset, since code-switchingimplies bilingualism. Further, how we define bilingualism has important implications for how we define code-switching. Some of the earlier literature on bilingualism reveals the assumption of a monolingual norm (Grosjean, 1985). This norm prevailed in North America up until the 1970's. Bloomfield's (1933) research illustrated well how language development was viewed entirely from one norm: the monolingual norm. He argued that a bilingual individual possesses complete control of the two languages in question; "In the cases where perfect foreign-language learning is not accompanied by a loss of the native language, it results in "bilingualism", native-like control of two languages" (p.55-6). Myers-Scotton (2006)takes an opposing view: " a bilingual is not a monolingual times two" (p. 327). Furthermore, Grosjean (1985) observed that such a monolingual viewpoint of bilingualism produced negative consequences. First, it affected how bilinguals evaluated both themselves and the society in which they lived. Second, pejorative labels such as Franglais (a mixture of French and English in Quebec) or TexMex (a mixture of Spanish and English in the southern United States) have often been applied to codeswitching. 
Similarly, Garcia (1983) argues that studies on child language should not assume a monolingual ideology. Gardner-Chloros and Ebooks (2009, p. 120)support this view; they contend that "one should study the bilingual majority rather than the monolingual minority". Wolck (1987) reports that almost half of the world's population is considered functionally bilingual, and that most of these bilinguals are first language bilinguals, which means that they were raised with two different languages. The present study will adopt Grosjean's definition of "bilingualism", which offers a more balanced view. According to Grosjean (2010, p. 22): "Bilinguals are those who can use two or more languages ... in their everyday lives".

\section{Language Differentiation}

Some scholars believed up until the 1980's that bilingual children started the language development of their two languages with one linguistic system. However, as the child got older, he was more able to gradually differentiate the two languages. Volterra and Taeschner (1978) were the researchers who had the most authoritative claim that children begin language learning with one system. Volterra and Taeschner (1978) suggested that there were three stages that all children passed through before they could be seen as a true bilingual. In essence, the first stage is characterized by the fact that the child has only one lexicon and one syntactic system. The second stage would entail a separate lexicon for each language, but still only one syntactic system for both of them. In the final third stage, the child has a lexicon and a syntactic system for each of his two languages. Volterra and Taeschner (1978) explain that this "Three-Stage-Model" (p.314) was the result of studying the linguistic development of two German-Italian girls, who were raised in Italy. It need be noted that Volterra and Taeschner's study insisted that language separation did not happen when children were in their early years of language development. However, there is now growing acceptance that children are indeed able to differentiate their languages early on (Cantone, 2008).

Language differentiation is significant because it is only when the child is aware that he speaks two distinct languages that he will be able to code-switch in the appropriate social context. Prior to this turning point, Gamal (2007) contends that the child may have been mixing the languages; however, it is not considered by most researchers as code-switching. Further, Gamal claims that once children are capable of identifying the context in which each language is used, and are consciously aware that they speak two languages, they will have successfully separated their two languages.

\section{Language Mixing}

The term "language mixing" is not clearly defined in the literature (Grosjean, 2010, p. 197). Lanza (2004) uses language mixing as a "cover term for any type of linguistic interaction between two (and potentially more) languages" (p.3). Likewise, Kôppe and Meisel (1995) contend that language mixing applies to any "utterance or conversation containing features of both languages" (p. 277). However, Cantone (2007) differentiates two different kinds of mixing. The first is described as early mixing, which normally stops at the age of three; she states that at this age, the child has combined a considerable amount of L1 with L2. Moreover, this author also contends that there also exists a second stage, whereby the child's mingling of the two languages is no longer concerned solely with grammatical elements, but at the same time it is also "pragmatically constrained by regularities" (p. 16). Although De Houwer (2009, p. 44) does not use the term mixing, she does use "mixed utterances" to address young children's language at an initial stage of language exposure; she also uses this same term to refer to systematic code-switching found in older children. In contrast, Tokuhama-Espinosa (2003) and Vihman (1985) label the initial period of a child's language development as indeed "language mixing...", but once children begin to realize that they are, in fact speaking two distinct languages, it is not seen as mixing any longer; it is now considered code-switching.

Although Tokuhama-Espinosa (2003) and Vihman's(1985) interpretation of "language mixing" can be seen as very precise, there does not appear to be a common consensus in the literature of what "language mixing" entails (Grosjean, 2010). Other researchers (De Houwer, 2009; Dopke, 1992; Juan-Garau \& Perez-Vidal, 2001) do not necessarily define language mixing in such exact terms. It is for this reason, that in the realms of this research, the meaning of "language mixing" will be as Lanza (2004) has defined it: a general term to relate to any context, in which two or more languages are used.

\section{Code-switching}

Code-switching is another term that requires clarification, as there currently exists no universal consensus among theorists as to its precise meaning. 
A common definition is that code-switching «...involves the use of elements from two languages within one utterance, conversational turn, or longer stretch of discourse» de Houwer (1995, p. 247). Given this definition, it is important to recognize that a child who uses two languages within one utterance, as well as across two utterances (as in a conversation) is considered to be code-switching. Some researchers (e.g., Myers-Scotton 2001; 2006) refer to the use of two languages within one sentence as "code-mixing". Others differentiate code-mixing, i.e., language switching within one sentence (intra-sentential) andcode-switching, i.e., language switching between either phrases or sentences (inter-sentential), including the tags and exclamations at either end of the sentence (McLaughlin, 1985) .

Blom and Gumperz (1972) argue that there are two types of code-switching: situational and metaphorical. Situational code-switching occurs when some change occurs in the situation, either in the participants, the topic, or the event. For instance, if two children, while playing together, use one language, and then they are suddenly joined by a third child, they may, for whatever reason, switch languages. For Gumperz (1982, p. 61), situational code-switching is "a simple almost one to one relationship between language and social context".

According to Gumperz (1982, p. 61), metaphorical (conversational) code-switching relates to how speakers "intend their words to be understood". Song (2007, p. 176) in his analyses of children's code-switching, contends that children often "negotiate through code-switching different or at times conflicting ideologies that accompany each language system".

In the present review, code-switching will be defined, as it has been by de Houwer (1995), as the use of two languages within the same sentence and/or within a conversation comprised of two or more sentences. In addition, this term will primarily focus on children whose families provide a context in which children are able to learn two individual languages.

And since the terms "code mixing" and "code-switching" have been considered to be synonymous by some authors(Backus, 2005; Eastman, 1990, 1992; Lanza, 2004), we similarly take the position that both "code mixing" and "code-switching" refer to the same phenomenon.

\section{Borrowing and code-switching}

"Anabel: Dad, how do you say Harry Potter in Spanish?

Father: There is no translation. It's the same.

Anabel: No, Dad, it's "Harry Potter" (pronounced as it is in Spanish)."

(Grosjean, 2010 p. 204)

Grosjean (2010, p. 58) defines code-switching to be "an alternate use of two languages". On the other hand, borrowing is claimed to happen when a person incorporates a word into another language. Poplack, et al. (1988, p. 52) support this view by defining borrowing as "the incorporation of individual L2 words (or compounds functioning as single words) into the discourse of L1, the host or recipient language, usually phonologically and morphologically adapted to conform with the patterns of that (host) language, and occupying a sentence dictated by its syntax". Grosjean provides an example, which illustrates a borrowing done by a child. In the example, the loanword is both morphologically and phonologically modified.

"Maman, tu peux me tier / taie mes chaussures?"

(Mummy, can you tie my shoes?) (Grosjean, 2010, p. 59)

In this sentence, the English word "tie" is embedded into the French sentence. The author claims that nouns are the parts of speech that are the most borrowed; they are followed by verbs, and then adjectives. Moreover, Grosjean explains that loan words, which can be nouns, may be altered morphologically as they are in the base language. For instance, this author provides an English borrowing in Spanish: "esa girl". He adds that the loanword may also be given a plural form or a gender if the base language calls for it. This illustration depicts how code-switching differs from borrowing. In one, the person is switching between languages, whereas in the other, borrowing becomes part of the languaHe adds that the loanword may also be given a plural form or a gender if the base language calls for it. 


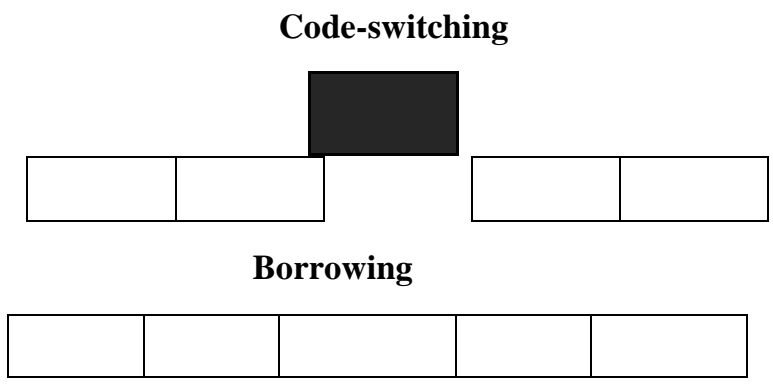

This illustration depicts how code-switching differs from borrowing. In one, the person is switching between languages, whereas in the other, borrowing becomes part of the language.

Figure 1.2 Adapted from Grosjean 2010, p.58

Collins (2005) distinguishes code-switching from borrowing, in that borrowing entails adapting the word as if it is part of L1. In fact, Collins claims that monolinguals see it as part of their language. In contrast, this author finds code-switching "...shows the real-time decision making of a speaker who controls, at least in part, two grammars" (Collins, 2005 p. 242).For the purpose of this essay, the definition of borrowing will resemble that of Pollack (1988): any single word or words, that come from L2 while conversing in L1, which are integrated into the language as if they were part of the language's syntax, is seen as borrowing. In contrast, language taken from L2 that does not change form, nor is it pronounced differently than it normally is, is identified as code-switching.

\subsection{Theoretical Approaches}

According to Heredia and Altarriba (2001, p. 166): "An important limitation of the research on code-switching is the lack of models from which to generate testable research hypotheses". Interestingly, in the two main approaches to general linguistics---the nativist approach (Chomsky, 1972; Crain \& Nakayama, 1987; Radford, 2004) and the functional approach (Bresnan, 2000; Croft, 2000; Hopper \& Thompson, 1980), the authors often cite literature on language acquisition and development tosupport their theories. However, child language is not as straightforward as it may seem, and in neither of these two approaches can data on child language be taken as conclusive. Hence, each approach inevitably encounters examples that do not support their hypotheses. Further, as de Korsak (2008) and Guasti (2004) insist, one should always begin with the data and, from there, move toward a theory that explains what children either do or do not do. Grosjean (2008, p. 21) equally maintains that viewpoint: "each type of human communicator, whether he or she uses a spoken or a sign language, one or two languages, has a particular language competence, a unique and specific linguistic configuration. Our role as researchers is to recognize this and to develop our methods of analysis to reflect this. It is only when we start studying bilingualism in itself and for itself that we will make additional headway in this field".Three theoretical models that help explain why people code-switch are presented below.

\subsubsection{Communication Accommodation Theory "CAT"}

This theoretical model was developed by the social psychologists Giles, Bourhis, and Taylor (1977) and came out of a series of interviews they conducted during the 1970's on speakers with various accents. Assuming that speakers are typically judged on the basis of the way they speak, they investigated the specific circumstances under which speakers would change the way they spoke during conversations. In the process of their investigation, they developed what they called "The Accommodation Theory", a theoretical model, which attempted to account for the kinds of choices speakers make while conversing with one another.

What this theoretical model asserts is that speakers are motivated to make changes in how they speak in order to be more favourably evaluated by their listeners. Such changes, however, might be either accommodating or disaccommodating (i.e., diverging). According to this theory, "Speakers tend to accommodate their speech to persons whom they like or whom they wish to be liked by, and they tend to diverge from those persons whom they do not like" (Myers-Scotten 2006, p. 155).

Some studies by Giles et al. (1977) examined conversations within bilingual groups, in which tensions had arisen over the use or value of the languages involved. The hypothesis they were testing was that speakers would show some sort of divergence if the other speakers threatened their language in some way. 
In an experiment in Wales, when Welsh-speaking subjects were asked questions in English that implied that the value of Welsh was being threatened by an English sounding voice (cassettes in a language lab), the subjects exaggerated their Welsh accents, while some even produced Welsh words and phrases in their answers (Giles, Bourhis, \& Taylor, 1977).

According to Myers-Scotton (2006, p. 158), accommodation and divergence are said to occur more at an unconscious than a conscious level. She further claims that speakers are equipped with a faculty that gets "filled in" through their experiences, and that allows them to make what are "ostensibly unconscious judgements". She also suggests that divergence, at times, may be a more conscious act, since it goes against the flow rather than with it.

\subsubsection{Markedness Model}

According to Nilep (2006, p. 12), the Markedness Model (Myers-Scotton, 2006), which identifies different types of code-switching as a form of markedness, has been the most influential theoretical model of social and pragmatic aspects of code-switching proposed since Gumperz's situational versus metaphorical switching distinction.

Although the Accommodation Model is primarily concerned with a speaker's convergence or divergence from the language of a listener or a larger audience, the Markedness Model has more to do with a speaker making choices on the basis of his own goals. Understandingly, however, the speaker needs to consider the listener's needs as well as his own since, if there were no listener, then there would be no conversation. What this model tries to convey is that there is a principled procedure that both listeners and speakers use to judge any linguistic choice they might either make, or hear as being more or less marked, based on the interaction in which it occurs. Moreover, this model assumes that a speaker develops a sense of intuition of which choices are acceptable for a particular interaction to be labelled as "unmarked". This act of knowing derives both from the speaker's prior experience in the community, as well as his/her "communicative competence" (Myers-Scotton, 2006, p. 159).

Myers-Scotton (2006) explains that unmarked choices are those that are more or less expected by the listener, given the context (i.e., the participants, topic, setting, etc.) of the interaction. Myers-Scotton (1993) developed A Rights and Obligations (RO) Model which clarifies expectations as to how an individual normally should behave in certain situations. In any particular language, the unmarked choice is the "linguistic" reflection of any specific RO set, but only in a specific context. To illustrate the notion of an unmarked choice, the author gives the example of a bilingual person living in France. For this person, the unmarked choice that is in use in a government office is French, and not any other language. In another example, that of a child whose mother is Spanish- speaking, the unmarked choice for the child would be to communicate with her in Spanish, especially if this is how they have always communicated with each other. In other words, whenever a speaker makes the unmarked choice, he or she avoids becoming the cause of any difficulty, given that the listener expects this choice, which is typically based on experience and community norms. Marked choices, however, are the main feature of the Markedness Model. They include linguistic choices that are neither predicted nor expected, given the particular RO set that is involved. Unlike their unmarked counterparts, marked choices exist for the sole purpose of "causing social ripples" (Myers-Scotton 2006, p. 159).

\subsubsection{The Negotiation Principle}

The Negotiation Principle is considered to be the "keystone" (Myers-Scotton, 2006, p. 160) of the Markedness Model: "Choose the form of your conversation contribution such that it indexes the set of rights and obligations (RO set) which you wish to be in force between speaker and addressee for the current exchange" (Myers-Scotten, 1993, p. 113).

Under this principle, any marked choice provokes a negotiation for a RO set other than the unmarked one that normally is expected. In more general terms, this negotiation involves both the speaker's persona (who the speaker is) and his/her relations with the other participants. It also typically involves issues of power or solidarity. Prosodic features, such as pausing and metacommentary on the switch, normally accompany marked choices. In short, speakers who make such code choices do so to "negotiate interpersonal relationships" (Myers-Scotton, 1982, p. 433).

Later, Myers-Scotten and Bolonyai (2001) developed yet another concept, "a rational code choice", which proposes that speakers rationally, either consciously or unconsciously choose a code or switch to another code in order to optimize their rewards and minimize their costs. 
The following example from Valdés (1978) illustrates "a rational choice" for code-switching. In conversations involving bilingual parents and their children, each 'side' may establish its own unmarked choice. In immigrant families, parents usually prefer the L1 as the unmarked choice, whereas their children usually prefer the dominant language (L2), of their community or environment. A specific example involves a 14-year-old son and his mother from south-western United States. Their conversation begins in English, but the mother switches to Spanish to express her annoyance with the way in which her son is chewing his gum.

Mother: An' then what?

Son: Well, we dint really say nothing.... Poncho got on his bike an' went off'.

Mother: Umm.

Son: Yeah...and...

Mother: Listen, your gum is driving me up a tree.

Son: He... took off...And.... (Son continues to chew his gum noisily.)

Mother: Tir el chicle y luego me dices

"Throw your gum away and then tell me"(Valdés, 1978).

\subsubsection{Conversation Analysis (CA) Approach}

A number of scholars have criticized Myers-Scotten for how she has applied the Markedness theory in her research (Auer, 1995, 1998; Cashman, 2005; Gafaranga, 2001; Jorgensen, 1998; Wei, 1998). First, they object to the importance she has assigned to the impact of external social norms on conversational code-switching. Second, they disagree with how she interprets the social meaning of code-switching. For instance, Auer, cited in MyersScotten (2006, p. 170), argues that speakers when switching codes, do not necessarily assume any "pre-existing normative model"; rather, he contends, they actively create and co-produce social meaning that is based on the particularities of the interaction.

Auer (1995, 1998) establishes four main principles that govern a Conversation Analysis (CA) approach tothe choices bilinguals make in a bilingual discourse: (1) CA analysts avoid using any "pre-established external categories"(Auer, 1998, p. 2) in their interpretation of the social meaning of bilingual code-switching. Instead, they assume that social meaning can be "locally produced" (Auer, 1998, p. 2); (2) CA analysts posit a level of "conversational structure" that is "sufficiently autonomous" with larger societal norms (Auer, 1998 p.3); (3) CA analysts pay attention to how the conversation is organized, as well as to the sequence in which the codes are changed. As Auer (1995 p.123) explains, "The situated meaning of code-alternation cannot be stated unless a sequential analysis is carried out. The same cue may receive a different interpretation on different occasions." (4) CA analysts, in general, are very meticulous when it comes to completing the transcript of any speech event. They consider it crucial to capture all potential nuances in how social meaning is produced.

Both the Accommodation Model and the Markedness Model are very different from the CA Model in how the latter interprets code-switching in any given interaction. First, the scientific approach used both by AM and MM scholars when analysing code-switching is deductive. In other words, they observe code-switching interactions on the basis of a set of premises about what the interaction is supposed to communicate. Only then do they seek empirical evidence that supports their initial premises. CA analysts, on the other hand, in attempting to interpret the same interaction, do so by using a more inductive approach. In other words, when examining a speech event, they do not begin by assuming pre-set ideas concerning the codes involved in the interaction.

Further, both the Accommodation Model and the Markedness Model are based on premises about the motives that speakers bring with them into a conversation. For example, in the Accommodation Model, choices are seen as attempts on the part of the speaker either to converge towards or diverge from the addressee's language preferences. The premise of the Markedness Model is that speakers make choices either to speak one language or to switch to another in order to "promote their self-identities" (Myers-Scotten, 2006, p.173). CA analysts, on the other hand, reject the notion that a speaker brings any intention in the interaction. Instead, they argue "that what goes on in the interaction will constitute whatever social meaning the interaction has (idea of locally arriving at the meaning of language alteration)" (Myers-Scotton, 2006, p. 173). In short, CA analysts seek to study the interaction between the speaker and the addressee in its entirety, before ascribing any social meaning to that interaction.

\subsubsection{Vygotsky andthe Socio-Cultural Approach}

Lev Vygotsky is well known in the field of psychology and although it has been over seventy years since his first 
published works appeared, his findings are still applicable today. One such finding, which is relevant to this particular review, is Vygotsky's socio-cultural theory of learning (Vygotsky, 1974, p. 165), which states that "consciousness comes about through situated, goal-directed, tool-mediated engagements in social practises". Vygotsky's theory is linked with what has come to be known as language socialization and internalization. According to this theory, all children are involved in a process in which they are "socialized" into a particular culture through a complex set of learning processes, by means of which a child becomes a member of his/her cultural group. Further, the internalization of these learning processes shapes the child's understanding of the world around him/her. This understanding applies to his/her "shared representations of language, including the development of meaning, the development of social scripts or schemata, and the motivational processes involved in learning or using a language" (Hamers \& Blanc, 2000, p. 111).Vygotsky (1974) holds the view that language plays a crucial role in cognitive development, especially afterthe child has mastered a certain level of language competence. Further, he argues that language, which is first developed through social interaction, is then internalized and becomes an important tool in shaping one's cognitive growth.

He further contends that being able to communicate in several languages will enable "the child to see his language as one particular system among many, to view its phenomena under more general categories, and this leads to awareness of his linguistic operations" (Vygotksy, 1974 p. 110).

\subsection{Chapter Three: Why Do Children Code-switch?}

Tokuhama-Espinosa (2003) claims that code-switching is an "intrinsic part of a bilingual child's language development" (p. 133). Further, Herdia and Altarriba (2001) contend that there are specific explanations to account for code-switching. In fact, they view alternating between two languages, as a means for bilinguals to be better understood. In the literature on child language development, several factors that can affect code-switching have been identified (Blom \& Gumperz, 1972; Lanza, 2009; McClure, 1981; Song, 2007).

In the scope of this essay, three important factors that influencecode-switching in young children will be discussed.

\subsection{Parental Discourse Strategies}

Lanza (1992) was the first to illustrate an importance to what is meant by discourse strategies, and the role that they play in bilingual language development. De Houwer (2009) states that "parents' ideas about which language they want their children to speak to them, or about the use of mixed utterances, are related to the attitudes regarding a particular language or the use of mixed utterances" (p.134). Further, she contends that these attitudes have a direct impact on discourse strategies that parents choose to use with their bilingual children. In fact, De Houwer (2009) defines discourse strategies to be "conversational patterns that express the speaker's wishes and expectations regarding language choice" (p.134). She explains that discourse strategies are known to have an effect on whether a child uses or not a particular language.

Dopke (1992) describes a study of six Australian families whose children were learning English and German. In each family, there was one parent who spoke German, and this was seen as the minority language. One aspect of her study focuses on six strategies that the German-speaking parent used when their child did not speak in the appropriate language.

The first two strategies were categorized as "non-response-eliciting" (Dopke 1992, p. 63). One was called "translations" and the other was "incorporating translations". Dopke explains that with these particular strategies, the child is not required to provide a response; they are "low constraint" (p.64). Below is an example of an "incorporated translation" where only part of the child's response is "incorporated" into the parent's language.

(Mother and child are painting a picture)

C: I make mouth for you

M: jawohl + ist der + der Mund auf der Stirn?

"yes + is the + is the mouth on the forehead?" (Dopke 1992, p. 64)

Further, Dopke provides four "response-eliciting" strategies that were also used by parents to influence their child's language mixing. The first one is "translation plus question" (p.64) The author states that this strategy, unlike the two others mentioned, begins to put a little more pressure on the child to communicate in the "appropriate" manner. When parents use this strategy, the child has to begin by understanding the parent's interaction in the other language, and at the same time, the child must switch to the appropriate language if he 
wants to be heard."Challenging question" is the next response-eliciting strategy that was used in the study by only one parent. It is described as a language game whereby the German speaking Father would ask nonstop questions in German to his son, Keith. Although the child did not want to speak German at the beginning of the dialogue, he finally switched to German at the end of the dialogue.

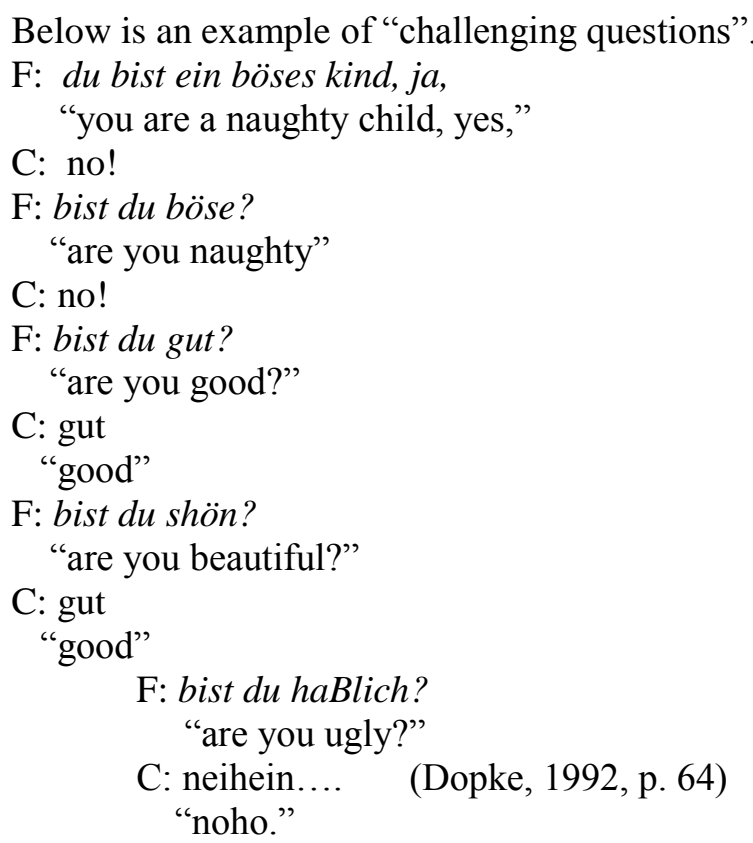

Dopke (1992) claims that although both strategies: "translation plus question" and "challenging questions" force the child to provide a response; it is normally a "polar response" (p. 64). When either of these strategies is used to convey to a child that the language he is using is not appropriate, he normally switches languages to give an automated response, as shown above, or to give a one-word response. Moreover, the two remaining strategies that Dopke observed in her study are "not understanding" and "request for transition". She explains that these two strategies elicit a "content response" from the child (p.64).

The author mentions that when parents use the "not understanding" strategy, they are, in fact, pretending to not understand the child's utterance simply because it is not in the appropriate language. In the sample below, it is shown that when the parent simply states that he does not understand, the child naturally repairs the communication.

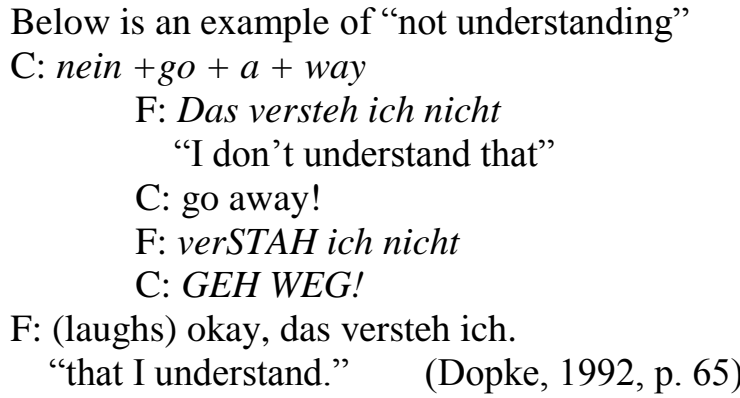

The final strategy that Dopke describes is "request to translation". She adds that this strategy opens up the possibility that a child may refuse to do as one has asked. Further, it does not allow communication to continue unless the child repairs the conversation breakdown. This strategy explicitly shows the child that the parent knows both languages, but he is only willing to continue communicating once the child has code-switched back to the appropriate language.

Dopke (1992)finds that strategies that elicit a polar response from the child are less coercive, however the two strategies that require a content response simultaneously add more pressure on the child to repair his speech. Table 2.1 illustrates a continuum of the six strategies examined in Dopke's study. All six are arranged from low to high constraint strategies: 
Table 2.1 Continuum of constraint exerted by insisting strategies

$\begin{array}{lll}\text { LOW I translations } & \begin{array}{c}\text { challenging } \\ \text { question } \\ \text { incorporated } \\ \text { translations }\end{array} & \begin{array}{c}\text { translations } \\ \text { plus question }\end{array}\end{array}$

(Dopke, 1992, p.67)

Dopke concludes at the end of the study, that the greater number of parents did not react in a negative manner if their child had addressed them in an inappropriate language. In fact, they continued conversing with them. Still, the author contends that the strategies that are explained above can influence a child to choose the appropriate language if he has not already done so. The author mentions that two of the six children reacted favourably to their parents using these parental strategies. As a result, their parents used them more often. Further, these two children were finally able to distinguish which language needed to be used with which parent.

Moreover, these same children were able to communicate in each of the languages, and they were even able to consciously decide to speak one language or the other to either parent. The author explains that only these two children were able to achieve this stage in their language development, which is known as stage three in Volterra and Taeschner's (1978) "Three Stage Model". This may be due to the fact that only these children were encouraged to speak German with both low and higher constraint strategies when they were in stage one and two, but yet when they had finally reached stage three of their language development, their parents systematically used more High constraint strategies. Further, since the children were more advanced in their language development, the parents could now use more higher constraint strategies more often.

In contrast, for the other four children, their parents favoured using both low and high constraint strategies during the entire time of the study. Perhaps one could suggest that parents use high constraint strategies on a regular basis once the child has reached stage 3 in his language development since at that point the child has the linguistic competence to avoid mixing the languages.

Likewise, Lanza (2004, p. 268) also devised a continuum of different reactions a parent can have towards the child's language mixing. However, Lanza's continuum does not refer to pressure on the child to speak the minority language, as in Dopke's classification. Lanza's continuum describes which kind of relationship a parent creates with his child when he mixes his languages: one that entails only one language, or one that includes two. More explicitly, in her study of two English dominant mothers, one mother used a parental strategy that discouraged the use of mixed utterances, whereas the other mother chose a strategy that allowed for such mixing. Lanza (1997) concludes that if a child is allowed to code-switch in her environment without experiencing any negative consequences, the parents are in fact saying to the child that code-switching is an acceptable manner of speaking. Furthermore, parents who choose to code-switch when conveying information to their children are reinforcing the idea that this way of conversing is well tolerated. Lanza's (1997) study also confirms that parents who do not allow code-switching in their homes greatly influence the extent to which their child will code-switch. This author claims that bilingual parents either move towards a monolingual context, or to a progressively bilingual context with any interaction they may have with their child's language mixing. Finally, she came up with five different parental strategies that parents can use to react to their child's language mixing. It need be noted that the first two strategies are taken from Ochs'(1988, p. 133)classification of "other-initiated clarification" strategies. These include: (i) Minimal Grasp, (ii) Expressed Guess, (iii) Adult Repetition, (iv) Move-on Strategy, and (v) Code-switching.

\section{Table 2.2: Parental strategies towards child language mixing}

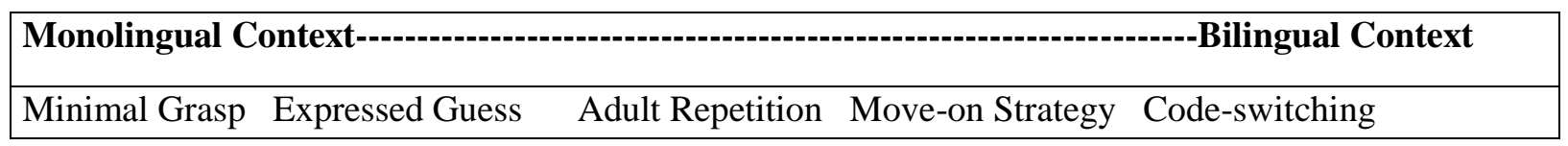

The monolingual situation is one in which the parent disallows any language mixing, but encourages all speakers, in any given conversation, to use only one language at a time. In the monolingual situation, there is only a "minimal grasp" of understanding when the child uses the "wrong" language when speaking to the "wrong" 
parent. The parent reacts by pretending not to understand the child's utterance. The child, on the other hand, soon realizes that he must speak the appropriate language if he wants to be understood. A parent makes an "expressed guess" when he gives the impression that to understand the child's utterance, he needs to ask a question. For instance, if a child says, "Je veux manger un pomme comme collation", the parent may react by asking the question, "You want to eat what?" This reaction elicits from the child what the parent wants to know, but only in the appropriate (preferred) language. If the child does not use the preferred language, then the child understands that he will not get what he wants. "Adultrepetition" occurs whenever a parent simply repeats what the child has said, but in the parent's language, with the expectation that the child will be motivated to do likewise. This often happens when a parent is reading with a child, and the child names an object in the other language. The parent will often repeat the same word, but in the parent's language, hoping that the child will do the same. The "Move-On" strategyoccurs when the child speaks in language X, and the parent responds by using language Y, as when a child asks, "Où est grand-maman?" and the parent responds by saying "She's sleeping".

Finally, the last strategy that Lanza discusses involves a bilingual conversation between the parent and child. In this case, the parent who prefers using a "code-switching" strategy with the child decides to use both languages, depending on which is more suitable for the conversation.

Taeschner(1983) allowed code-switching in her household after she had come to feel that language differentiation was no longer an issue, and that her two children had become balanced bilinguals. Garcia (1983) notes that when parents code-switched when conversing with their children, the children did not necessarily, as a result, use more mixed utterances. In addition, Gardner-Chloros and Ebooks (2009, p. 144) argue that many families who claim to be strict adherers to the "One Person One Language" method have been observed to be "subconsciously"codeswitching themselves; even though they normally contest such language practices (Barron-Hauwaert, 2004; Goodz, 1989; Juan-Garau \& Perez-Vidal, 2001; Lanza, 1997).

Huerta (1977) provides a study of a child who was raised by a mother who chose to code-switch consistently with her child. Two languages were used simultaneously in the household: English and Spanish. Heurta (1977) states openly that her son became bilingual only because she herself had decided to use a code-switching mode as their main manner of speaking. Heurta concluded that it is not necessarily the case that children who are encouraged to code-switch in the home are less likely to become bilingual.

Tabouret-Keller (1969) provides one of the few studies that examine a working class female child in relation to how she is socialized into a code-switching behaviour, mainly as a result of the input of her parents. The community also contributed by indicating that code-switching was acceptable. The child in this study, whose name is Line, was observed at six years of age to be code-switching between French and Alsatian, in much the same manner, as did the adults who surrounded her on a daily basis. The author concludes her study by stating that her results resemble what actually happens in the lives of most bilingual children in today's world, namely, that their language is moulded both by their parents (Gardner-Chloros, 2009; Goodz, 1989) and by the community at large.

Juan-Garau and Pérez-Vidal (2001) analyse parental discourse strategies in a family who uses the one person-one language input pattern. They observed that parents apply various strategies to react to their child's codeswitching. In their study, there is one child whose father is English speaking, whereas his mother is Catalan speaking. Moreover, both parents are proficient in Catalan, French and English. What is interesting about this case study is that the mother and father do not necessarily react to their son's language mixing inthe same manner. Andreu's mother most preferred strategy is "the move-on strategy" (when the child speaks in language X, and the parent responds by using language Y). Juan-Garau and Pérez-Vidal (2001) explain that the mother creates a bilingual setting with her son when she uses this particular parental strategy. In fact, it was observed that the mother, at times, code-switched with her son, which clearly, once again, "negotiated a bilingual context" (p.72). When the mother was seen code-switching, it was for individual words for which her son did not seem to know the bilingual equivalents, and the authors mentioned that it was occasional. Most often, she used simply the "move-on strategy". There is another strategy that the mother also used, which is "the repetition strategy"; however, the authors state that this tactic to curtail language mixing "does not force the child to locate the trouble spot in communication" either, much like the "move-on strategy (p. 74). Yet, it does provide the child any lexical or grammatical form that the child is not able to produce. Consequently, the child often is found to switch to the same language the parent is speaking to carry on the conversation. However, the authors claim that when children do not know how to say certain elements of a sentence, it often results in language mixing. 
Andreu's mother did not often converse only in one language with her child in the study. For instance, she rarely used the "minimal grasp strategy" (the child uses the "wrong" language, when speaking to the "wrong" parent, the parent pretends not to understand) and the "expressed guess strategy" (the parent gives the impression that to understand the child's utterance, the parent needs to ask a question), which are both intended to identify the problem area of the message and fix it. Juan-Garau and Pérez-Vidal (2001) point out that at times, the mother would use minimal grasp to repair the communication; however, the child did not see it as a sign to stop codeswitching between his two languages. The authors state that this is, in part, due to how the mother transmits her message; she does not single out any particular problem to be corrected. She finds the quickest solution. One can assume that if the parent did illustrate to the child where the trouble spot was in his sentence when she used the minimal grasp strategy, and furthermore, if she clearly showed the child that he needed to code-switch back to the appropriate language before communication could continue, the child would have made the association that it was his mixing of the two languages which was the issue, and it could have influenced future mixing. The father, on the other hand, was observed to be using more of a variety of strategies to influence his son's language mixing. This was expected since Andreu's minority language is English, which is the language that his father speaks.

Since Andreu was more often found mixing when he spoke English, his father was naturally using different parental strategies to re-establish communication moreoften than the mother. The authors explain that both parents used a bilingual context with the child (the move-on strategy), until the child was three years old. Their reasoning was that their son was learning the basics of each language; however, when Andreu turned three, the father changed the strategies that he used when reacting to his son's language mixing. From that point on, the move-on strategy was not totally abandoned, but the father expected Andreu to be more able to function in a monolingual context in English. As a result, this decision had a direct impact on the child's mixing: it decreased rapidly. Moreover, the father was the only person with whom Andreu could communicate in English. This reality made the father realize the importance of being consistent with communicating in only English with his child, and not allowing himself to perform any code-switching whatsoever.

At the same time as Andreu turned three years old, he spent three weeks in England with his extended family. This trip definitely allowed him to have more of a command in English, and at the same time did not encourage him to code-switch because his visit in England enabled him to have increased his bilingual equivalents in the minority language. The father changed from using predominately a "move-on strategy" to using a "requests for clarification" strategy. If we refer to Lanza's continuum of parental strategies, "requests for clarification" refers to "minimal grasp" and "expressed grasp". Juan-Garau and Pérez-Vidal (2001) point out that when parents use these two strategies with their children to deter them from mixing their languages, they are simultaneously making them aware of the family's bilingual identity. Moreover, Andreu's father normally used "minimal grasp" as an initial strategy to influence his son to switch in the appropriate language. Both Saunders (1988) and Taeschner (1983) claimed that pretending to not understand when their children used the other language indicated to the children that they needed to change languages. However, if using the "minimal grasp" strategy did not create the desired result, Andreu's father would use the "expressed grasp" strategy. Juan-Garau and Pérez-Vidal (2001) warn parents that for "the minimal grasp" strategy to work, the child needs to have the required translation equivalent in his repertoire. If the parent is not sure that the child has it, he is encouraged to use the "repetition" strategy because it repairs the conversation breakdown, and it also "helps the child recast his mixes" (Juan-Garau \& Pérez-Vidal, 2001, p. 79).

Although Andreu's father had been progressively using more of the "expressed guess" strategy with his son prior to his third birthday and after, it was not until Andreu was 3.2 years old, that he, himself, realized that when his father used this strategy, it was a clear sign for him to switch to English. Prior to this age, Andreu did not perceive this strategy as an indication that he needed to change languages.

Juan-Garau and Pérez-Vidal (2001) conclude that Andreu's mother used primarily the "move-on" strategy, as well as a "code-switching" strategy. The effect that this choice had when the mother suddenly requested clarification, was that Andreu did not interpret this strategy as a sign to continue in a monolingual context. In contrast, once the child had turned three years old, his father mostly used parental strategies that enabled both him and his son to converse in a monolingual context. The authors explain that normally it is the parent who speaks the minority language who is more concerned with establishing a unilingual context with the child. In Lanza's (1992b) study, Siri, the mother, reacted much like Andreu's father. Both spoke the minority language, and both strived much harder to establish a monolingual context with their child. 
Juan-Garau and Pérez-Vidal (2001) do state that language mixing normally begins to disappear as the child gets older. In addition, parental strategies that are used to deter a child from code switching have a tendency to vary, as children grow older.

Another factor that had an impact on Andreu's mixing in English is the quality of the interaction that the father had with Andreu. Saunders (1982) concluded that parents who develop an engaging relationship with the child can have a positive influence on the kind of output the child speaks. Juan-Garau and Perez-Vidal (2001) witnessed the same observation in their study. In fact, the father used a particular strategy that he, alone created; it was called "the monolingual puppet" strategy. In this study of language development, Andreu spent roughly as much time with the father as the mother. Further, the father worked hard at creating a rich atmosphere whereby Andreu played, read and discussed lively topics with his father. One activity that he enjoyed was speaking with the father's puppet. The father explains that the puppet strategy was helpful in drawing out of Andreu vocabulary that the father knew his son knew in both languages. This tactic used with the puppet corresponds to a "request for translation" discussed by Dopke (1988).

Juan-Garau and Pérez-Vidal (2001) observed that a parent's attitude toward a child's code-switching can also have an impact on which strategy he chooses to apply or use with his children to react to his son's language choice. Barron-Hauwaert (2004) adds that parents need to understand that their attitude towards code-switching in the household is important, as is the degree of acceptance they show towards their child's code-switching. This author further states that parents differ with respect to their children's language development in two languages. While some parents agree to carry on a "bilingual" discourse with their children (Heurta, 1977), others disallow any mixing and demand a monolingual conversation at all times (Fantini, 1985; Leopold, 1949).

Finally, Lanza (1997) similarly concludes that detailed taped observations of parents, and of the manner in which they communicate with their children, illustrate well that parents' attitudes and acceptance are very important in the eyes of their children. Furthermore, this supports the assertion that the child's output in language is, in part, directly affected by the parents' tolerance. For instance, Arnberg (1987) observed in her study that mothers accepted to be addressed by their children in their dominant language (the dominant language of the children). Consequently, Arnberg warns that this indirectly encouraged the children to not communicate in the minority language, which was the one spoken in the household. This suggests that when parents are not conscientious about how they are communicating with their children, they may be indirectly influencing their child to codeswitch because of a language gap.

\subsection{Language Proficiency}

Proficiency is another factor that plays an important role in code-switching (Gamal, 2007; Heredia \& Altarriba, 2001). In fact, both Romaine (1995) and De Houwer (2006) maintain that when a young child grows up in a community in which language mixing is the norm, then these children receive input whichsimultaneously derives from two different codes. De Houwer further claims that these same children who only hear two codes mixed together are not actually language proficient in either of the two distinct languages. In short, what De Houwer states is that if a child is not fluent enough to carry on a conversation in either L1 or L2 without any language mixing, this child's speech cannot be then identified as code-switching (Gamal, 2007; Sridhar \& Sridhar, 1980). In this section, the role of proficiency in code-switching is discussed. Applications of The Accommodation Theory (Giles, et al., 1977) will also be explored.

It has been observed that bilingual children are often more able to converse in one of the two languages. This is known as their dominant language, which is due, in part, to greater exposure to one of their languages(Paradis \& Nicoladis, 2007). Genesee, Nicoladis, and Paradis (1995) argue that language mixing and the issue of language proficiency are inter-linked. Petersen (1988)also contends that language mixing is influenced by language dominance.

Quay (1995) supports this view that a young bilingual child's code-switching is primarily due to lexical gaps in his/her lexicon. Unlike other authors (Volterra \& Taeschner, 1978) who attribute language mixing in children to a lack of metalinguistic awareness, Quay's hypothesis is that it may very well be that the child does not have the necessary translation equivalents to make possible language choices. To shed light on this, Quay discussed a bilingual case study of an infant followed from birth to age 1; 10. The author investigated whether or not a young bilingual had the resources to make lexical choices at a pre-syntactic stage of development before the age of two. 
In her conclusions, Quay (1995) found that the child had the necessary translation equivalents in his lexicon for him to make possible language choices. Since this was a case study of only one child, the results should be considered important, but not conclusive. These findings might remind us of the danger of quickly assuming that a young child mixes the language because he has not yet differentiated them; it may be the contrary: the child does know which language he is using, he simply lacks the essential elements to fill in his lexical gap.

Although a child is more likely to code-switch when he is speaking in his less proficient language, Fantini (1985) illustrates that it is not always the case. This author relates an example of Mario accommodating a child when he was around 2.5 years old. One day while he was shopping with his mother, he noticed a young girl with whom he wanted to communicate. What was interesting to observe is that at this young age, Mario addressed her in English with words like: "Hey! Look! Watch! Here! Come! And Water! (he was pointing to a water fountain" (p.44). Despite the fact that he was only two years old, and that English was clearly his weaker language, he "judiciously avoided Spanish" (Fantini, 1989, p.44). What Fantini (1985) has observed illustrates that dominance in one language, does not necessarily mean that one will code-switch when using the nondominant language; other factors may come into play. These results are also confirmed by Lanza (1997) and Gardner-Chloros (2009). Zentella (1997) also provides examples of lack of proficiency as a reason for code-switching. For instance, one of the children she studied used code-switching as a relief strategy for any lexical gaps she may have had. In fact, Zentella says that her code-switching enabled her to appear more proficient while speaking; she was no longer stopping to search for a lexical term.

Further, Shin and Milroy (2000, p. 44) contends that the proficiency of the addressee can also have an influence on whether or not the child will code-switch. Vu, Bailey and Howes (2010) state that "being sensitive to the language capabilities" of the addressee, is a reason for which young children code-switch (p.202). Clearly, the Accommodation Theory (Giles, et al., 1977) can be applied in this context since the child is indeed motivated to speak the appropriate language, in order to accommodate the interlocutor.

Grosjean (2010) observed that once the child has assessed from observing the environment which language that the person speaks, he begins speaking the same language. However, if the child notices that the participant is using his weaker language, the child will automatically change for the other language (p. 195). Fantini (1985) adds that when his son, Mario, was between five and six years old, and when "he sensed that others spoke in an "artificial" manner, he normally switched back to English, often despite their attempts to maintain the conversation in Spanish" (p.62).

Shin and Milroy (2000) explain that normally young children naturally choose to communicate with the interlocutor in the language that the child prefers, provided the interlocutor is equally proficient in the same language. Zentella $(1981 ; 1997)$ supports this observation; however, she has observed that younger children are more likely to address the participant in the language that they were spoken to. However, she noted that older children may opt to use the language that they, themselves, prefer, provided, as Grosjean has also concluded, that the participant knows the language the child intends to use. In Zentella's study, some of the children were able to communicate well in both English and Spanish, whereas others were more proficient in Spanish. She considered that the children who were more dominant in Spanish might feel comfortable using both languages if they were addressed in their weaker language, provided that this linguistic behaviour did not create any problems with the participant. Shin and Milroy (2000) point out that if the language the child chooses to use makes it difficult to converse with the interlocutor due to a lack of proficiency on the participant's part, the child will accommodate the interlocutor.

McClure (1977) similarly argues that young children deal with an interlocutor's proficiency by simply deciding if the participant can speak the language or not. Once the child has assessed which language the interlocutor speaks the best, he changes to the same language accordingly, without any hesitation, as seen with Mario in Fantini (1985). Genesee and Nicoladis (2006) affirm that the fact that children are able to adjust their language code while they are interacting with the interlocutor is very much a skill. Moreover, these two authors add that the child is able to do this without any prior knowledge or experience with the addressee.

Finally, Gardner-Chloros (2009, p. 145; Lanza, 1992b) explains that in a bilingual environment, child codeswitching "alters in type as they grow up, owing to their maturing metalinguistic capacities, as well as their increasingly sophisticated linguistic competence". In fact, Lanza (1992b) confirms that there is indeed a difference in the young child's code-switching from that of older children. In essence, both Gardner-Chloros and Lanza are conveying that a young child code-switches because he is less proficient in one of the languages that he 
is using to convey his message; there is no other. Yet, as the child ages, he gradually develops other reasons to change from one language to another. He is no longer deciding to code-switch simply due to a language gap (Gardner-Chloros, 2009).

\subsection{Contextual Situations}

In this section, we will discuss precisely howthe context in itself leads a child to code-switch.It has already been shown that children's code-switching is primarily situational: some changes occur in the situation, whether in the participants, the topic, or the event (Fantini, 1985; Genishi, 1976). Fantini (1985) finds that when code-switching is used in this manner, factors such as, interlocutor, setting, function, role and topic, can explain why codeswitching happens.

Lanza (1992b) was one of the first researchers to openly request "the need to examine more carefully the role of context in the language mixing of young bilinguals". In her study of language mixing with the Norwegian child, Siri, Lanza concluded that Siri did in fact "differentiate her language use in contextually sensitive ways" (p.655). Moreover, Gumperz (1982) who coined the term "situational code-switching", describes it as "a simple almost one to one relationship between language use and social context" (p.61).

Further, this section will illustrate how children's code-switching can be seen as inherently positive and constructive. In fact, Myers-Scotton (1993, p. 75) contends that children who code-switch come to be viewed as "a rational actor". Once they become aware of the two linguistic codes in their environment, they begin to make conscious or unconscious choices to code-switch or not.

Both Vygotsky's socio-cultural theory of learning (Vygotsky, 1974) and the Markedness model (Myers-Scotton, 2006) can be referred to, in order to better understand how this linguistic phenomenon unfolds in a child's understanding.Koppe and Meisel (1995) propose that a child's ability to choose the appropriate language when addressing an interlocutor be considered as the first pragmatic function of code-switching. In fact, Ervin-Tripp and Reyes (2005) write that the addressee is very prevalent in children's language choices (p.92). Koppe and Meisel continue by stating that this first function is developed quite early in young bilinguals. Meisel (1994) explains that children as early as 2:0 are able to code-switch. Lanza (1997) similarly observed that Siri was able to speak the appropriate language, depending on the interlocutor at a very young age. In the following sentence: "Quiero comer un cake" (I want to eat a cake), Vu, Bailey and Howes (2010) explain the child has used the English word instead of its Spanish equivalent. De Houwer (2005)contends that this way of communicating for children two years old or younger is claimed to be the child's primary form of code-switching until he is around 4 or 5 years old.

It has already been shown that in the early stage of language development, bilingual children are able to select the appropriate language with their parents (Genesee, Boivin, \& Nicoladis, 1996). Shin and Milroy (2000) identify this use of code-switching as "participant code-switching" (p. 381) In this context, the child naturally speaks a specific language with each parent. What is meant by "naturally" is that the child speaks the language expected of him by his important role models. However, Koppe and Meisel (1995) point out that the factor "interlocutor" may become relatively complex when the child is in contact with an unknown bilingual interlocutor. The child has to decide if the interlocutor wants to be addressed in only one language or two. Further, the authors explain that this first pragmatic function of code-switching can be used during conversations with monolingual or bilingual individuals.

Boivin, Genesee and Nicoladis (1996) claim that bilingual children are able to address an unknown interlocutor with the appropriate language by the time they are two years old. Further, Genesee (2001) concludes that children are even able to perform this skill "from the one-word stage of development" (p. 164).

Fantini (1985) illustrates in his study how attributes of unknown interlocutors had an effect on his son Mario. He reports that when Mario met an unknown person, his son had to decide which language he was going to speak. It was not difficult for him if he was in a Spanish-speaking environment; the code which would be used was obviously Spanish. However when the setting was in an English speaking environment, he would choose English, unless Mario noticed that the speaker might be Spanish due to the way that he looked (Fantini, 1985, p. 60). Grosjean (2010) adds that "extensions of the setting" (p.194) such as the telephone, radio or television similarly influence the child as to which language the interlocutor speaks. Moreover,Saunders (1988) contends that the participant's mere presence in a room is enough to influence a child's choice of language. The interlocutor may even be a toy or an animal (p. 74). 
Fantini (1989) reports that characteristics like the participant's age, gender, or occupation did not seem to play a role in the child's code-switching. However, Mario's example above(Fantini, 1985) illustrates that the participant's physical attributes did make an impact. Zentella (1997) similarly reports in her study that physical features influencecode-switching, but also adds that gender and age do as well. Vu, Bailey and Howes (2010) affirm that age is, indeed, a deciding factor as to why a child code-switches. They explain that the amount of input in a particular language is directly linked to the age at which a given language was introduced to the child. For instance, a younger child may code-switch more than an older child since he has had less linguistic input than an older child who has been speaking the languages longer. In contrast, an older child who has had more input from both languages will not necessarily need to use items from L1 while speaking L2.

Furthermore, Comeau, Genesee and Lapaquette (2003) found that children are even able to accommodate their interlocutor, not only in the language that he chooses, but also in any code-switching he does.

These authors performed an experiment to verify whether children are able to match the frequency of codeswitching by unknown interlocutors in a turn-by-turn analysis. It was observed that when the stranger changed his rate of mixing from $15 \%$ to $40 \%$ and then once again to $15 \%$, the children did likewise. Finally, this experiment shows that children are capable of modifying their language choice to truly respect that of their interlocutor. Moreover, it provides an example of "Follow the leader..." which suggests that children would switch if an adult switched the language of the conversation (Zentella, 1997, p.86).

McClure (1977) states that the topic of the discussion does not have as strong an impact on language choice as participant or interlocutor. Yet, she does admit that certain topics are more likely to be explained in one language more than another. Zentella (1997) explains in her book "Growing Up Bilingual" that for several of the children in her study a topic shift tended to trigger a code-switch for young children. To account for the reason why this particular strategy was used as muchas it was by the children, she points out that often, the topic shift was made at the same time as there was a change in the participant (addressee or interlocutor). Each code-switch that was used to signal out a change in addressee was also counted as a topic shift.

Surprisingly, Fantini (1985) noted that Mario, her son, had rarely performed any code-switching by topic until he was ten years old. He mentions that before this age, some topics that dealt with English experiences were more likely explained by borrowing rather thancode-switching. However, once his son began to study more complex subjects related to school such as math and science, his "tendency to switch codes intensified" (p.73) simply because he was learning more complex information that he did not necessarily know in L1. Fantini gives an example from when Mario was 10 years old and was spending an afternoon at a lake with friends. Although they were speaking about swimming in Spanish, Mario suddenly switched to English when he wanted to explain how to do the crawl stroke. He did not have the necessary Spanish words to explain this concept.

McClure (1977) observed in her study that topics that are connected to "family-child care, kinship, and food preparation are most discussed in Spanish; whereas sports, school, and holidays such as Halloween and Thanksgiving are more often discussed in English" (p. 19). For instance, Halloween is a topic that is more often discussed in English because this is a tradition that is more celebrated in English than in Spanish culture. Bader (1998) gives an example of an Arabic-English child who switched to Arabic when referring to vocabulary for items that are found outside of the house; however, he code-switched to English each time he referred to indoor items.

$\mathrm{Vu}$, Bailey and Howes (2010) propose that the code-switching that children perform can be categorized into two different switches: "Realignment and Clarification: code-changes appear to serve a socio-pragmatic, or an interactional function, namely in either realigning the conversation with the interlocutor, or in clarifying what was said" (p.206). In addition, Vu, et al., (2010) admit that this classification of children's changing of codes was directly influenced by Zentella's (1997) and McClure's (1977) research on children's code-switching. Gumperz's (1976) findings on conversational code-switching were also considered.

Furthermore, Vu, et al., (2010) explain that "Realignment Switches" happen when a child code-switches to alter "the direction of either her/his own speech or the interviewer's speech" (p.206). For Shin and Milroy (2000), this kind of code-switching is seen as "a contextualization strategy" to better allow a child to say what he wants to say. Below, you will see a list of the realignment switches that $\mathrm{Vu}$, et al., suggest are the most salient factors that incite young preschool children to code-switch.

1.Topic shift: Shift in topic that accompanies the switch; no consistent link between topic and language.

Child: $\quad$ t: Can we do that? Okay, because I'm really... 
Interviewer: $\quad$ t: I know...

Child: $\quad$ t: Adonde vair ella?

e: Where is she going to go?

2.Quotation: Child recalls or makes up speech and reports it directly or indirectly.

t: Primero estaban parados y dijeron. "We, we came home".

t: First they stopped and said, "We, we came home."

3. Role shift: Child changes languages when he/she changes roles; differs from quotations as the child takes on the character of another person.

t: Van a llorar y se van a ir a la calle. Goodbye, goodbye, niños vengan par acá.

e: They were going to cry and they were going to go to the street...Goodbye, goodbye, children come this way.

4.Narrative frame break: Child departs from the narrative frame in order to evaluate an aspect of the story.

Interviewer: $\quad \mathrm{t}$ : $\mathrm{Y}$ Ana se le iba a caer

e: And Ana went to fall.

Child: $\quad$ t: Right, ya.

5.Checking: Child switches in order to seek the interviewer's opinion or approval.

t: Esta se va resbalándose, pero se agarra y esta se va resbalándose pero parada, este se va parado pero resbalado. Right?

e: This slipped, but it take a hold of itself and this slipped but stopped, that stopped but slipped. Right?

6. Mitigating request: Child code-switches in order to make a request.

Interviewer: t: A ver? qué pasa?

e: Let's see, what happens?

Child: $\quad$ t: Tú please

e: You please.

7.Attention attraction: Child code-switches in order to call for the interviewer's attention.

Interviewer: $\quad \mathrm{t}$ : Entonces aqui...entonces aqui en al cocina...

e: Then here...then here in the kitchen...

Child: $\quad$ t: No, wait.

Table 2: (Vu, et al., 2010, p.206)

$\mathrm{Vu}$, et al., (2010) add that "Clarification code changing" switches (p.207) were switches that had primarily one function in mind: to clarify an utterance in some manner. Often, when children use this strategy, it usually takes the form of translating something.

Translations: Child code-switching to translate a statement, command, question, etc.

Child: t: Si. Dame, dame el negro.

e: Yes, give me, give me the black one.

Interviewer: t: El negro, ¿qué negro?

e: The black one, what black one?

Child: $\quad$ t: El black.

e: The black one.

Table 2: continued: (Vu, et al., 2010, p.207)

Zentella (1997) noted that "Clarification and / or Emphasis" (p.95) was the most commonly used function of code-switching for the children in her study. Furthermore, she explained that the community in which she did her experiment had in general a negative attitude towards the variety of ways code-switching was used to help 
communicate more effectively. One strategy that the community did appreciate was translation; "it was honed a valuable skill"(Zentella, 1997, p. 96).

McClure (1977) noticed in the children's code-switching that "Attention attraction" and "Emphatic codeswitching" (p.26) were the most common, regardless of age. She provides an example for "Emphatic codeswitching": T (boy, 8): Yo soy segundo. I'm second! Paugh (2005 p. 63) notes that school age children codeswitch for many pragmatic reasons: "such as structuring play, games, and other activities, negotiating meanings and rights, and asserting their shifting identities and allegiances".Fantini (1985) points out that the form or activity that the child may be performing can equally play a role in eliciting code-switching. She defines form "as the message couched in a special form, as distinct from that used in normal conversation" (p.59). Moreover, Lanvers (2001) observed the same phenomenon when children are around three years old, their code-switching is also characterized by the form of the dialogue. For example, Lanvers claims that the form of dialogue that the child decides to use when he is talking can influence his code-switching. If he is in the midst of story telling, or playing a game, one form of dialogue may influence him more than another to code-switch. Kwan-Terry (1992) observed similar findings with her son who claimed that imaginary animals or characters communicate primarily in English.

Although a change in context can influence a bilingual child to accommodate with the addressee, contextual factors can as well insight a child to provoke his entourage (Giles, et al., 1977). Further, Myers-Scotton (2006) claims when a child chooses to behave in a manner that is not expected of him, the child's language choice is more likely to be "marked".

Fantini (1985) illustrates that when Mario had an intention either to surprise or shock his interlocutors, he would often use a language code that was not the one that was normally used in such a context. For example, "when Mario wished to amuse his parents, he jokingly spoke in English; to tease his grandparents, he sometimes rattled words off in Spanish; to exclude his aunt, he defiantly persisted speaking Spanish in her presence in spite of her protests" (Fantini, 1985, p. 66).

Vu, et al., (2010) illustrated in their study that preschool children are able to use marked utterances as well. For instance, when they commented about "Mitigating request" and "Attention attraction", which are two of the many functions of code-switching, they specified that these particular ones, among others (see: 3.3.1) are "realignment switches: realigning the conversation with the interviewer..." (p.206). In contrast, Zentella (1997) sees the same two functions as an intent to "Appeal and /or Control" (p.95); she does not categorize this function under "Realignment", because it goes further than simply "shifting away from your initial focus" and realigning yourself with a code-switch (p.93). Zentella says that these functions, and one other: "Aggravating requests" are all used to "direct the addressee's behaviour by means of imperatives tinged with threats or entreaties" (p.95). All three functions serve as sub-types of "Appeal and/or Control". What Zentella is saying is that these specific kinds of code-switching are accompanied by a change in intonation, and there are "other signs of aggravation or mitigation" (p.95). In fact, Valdés (1978) is known to be one of the first to suggest that code-switching can also be used when our intent is "getting mad" (p.95). Finally, Zentella's (1997) research acknowledges that this more intense kind of code-switching is very prevalent in adult dialogue. Consequently, this could lead us to believe that this particular intent increased as the child becomes older. Although preschool children can equally use codeswitching to make a marked utterance, their code-switching is more often of a converging nature. For instance, Saunders (1988) observed a three-year-old child who code-switched to include another child into his circle of friends. Preschool children are more likely to use code-switching to communicate; and it is more generally accommodating than in older children.

Ervin-Tripp and Reyes (2005) point out that children "can ignore or avoid access to one of the varieties available to them" (p.85). The authors illustrate this by referring to preschool age children. When children are at this age, they begin to be more motivated to speak with some individuals, while ignoring others. More precisely, children want to give more attention to one individual and not another. As a result, this individual would be the one that spends the most time with the child. What comes from this? The authors suggest that at the same time as the child is selecting certain individuals to listen to, or be understood by on a regular basis, he or she is choosing to be socialized as to how to behave linguistically. Ervin-Tripp and Reyes claim that this is precisely why children often "sound more like their peers than their parents" (p. 85). 
One other point that these authors make is that children in general want two things: "The desire to sound like others and to be seen as an insider who shares the same values" (p.86). This also suggests that the way that their friends speak could be very much be a deciding factor as to why they code-switch.

Moreover, McClure (1977) claims, "there appears to be a characteristic pattern of language use associated with every identity relationship" (p.16). For the purpose of this essay, social identity is a function of the "contextually sensitive ways" that can impact a child to code-switch (Lanza, 1992b). When children are very young, any social identity that may develop would generally be between the parent and child. However, as the child gets older, and his intimate circle enlarges, the community enters more and more into his world.

The outcome of this is what McClure has concluded in her findings: "Language alternation to mark a shift in identity relationship, is of course more common among older children than among younger children since the former have access to more identities" (p.17).

Zentella (1997) reports instances in her study of bilingual Puerto Rican children for whom social identity had an impact on whether or not the children code-switched. For instance, even though the children were bilingual in English and Spanish, they automatically spoke to a stranger in English unless they knew that he was able to converse in Spanish. Vu, Bailey and Howes (2010) explain that a child naturally begins a conversation with strangers in English because this is what normally happens to all individuals for whom Spanish is their mother tongue, and who live in the United States. In other words, what is being communicated is that Spanish children have concluded that in the United States, most people speak English, so if you do not, you code-switch when speaking with a newcomer.

Paugh (2005) provides another example of how social identity plays out in a community to have an impact on language choice. This author studied children playing with other children their age, known as "peer play". What is interesting about this study is that it observed a country named Dominica, located in the West Indies, where the adults primarily code-switch between English and Patwa, which is a French lexicon Creole. The children, on the other hand, are forbidden to do so. More explicitly, code-switching is reserved for the adults and children are expected to speak English. In fact, English is known as the formal language at school and for church and village meetings. For more informal situations such as getting together with friends or family, "Patwa is considered by most to be "better" for emotionally expressive speech acts like gossiping, arguing, joking, cursing, teasing, and assessing others" (p. 67). In this particular study of children's code-switching, whose ages are between 2 to 13 years of age, we are able to have a glimpse of how they are socialized through language on how to "talk like adults". For instance, in one example of role-playing, one child acts like the mother, and her little brother pretends to be her baby. As mothers often do with young children in this community, the older child-mommy lifts her shirt and grabs her brother close to her, while saying, "Baby, look tété" (baby look breast) (Paugh, 2005 p.70). The author explains that mothers often code-switch like this when they are breast-feeding their babies. On the other hand, if the children are now "bus drivers", they switch to Patwa, and tell the passengers to "Batjé batjé batjé" (Get on board, get on board, get on board) (Paugh, 2005 p. 74). As illustrated with these examples, peer play allows children to experience a variety of identities in a safe place where adults cannot be found. In this community, children could role play how adults live, only in the yard, or in "the bush" since in the house, or even close by on the veranda, the children would be reprimanded if they were caught code-switching in Patwa. Curiously, in this study, a grandmother had indeed overheard "Marcel" who was using Patwa too close to the home even though his peers had warned him not to do so. When the grandmother punished him, she used "the Patwa address term: mouché Marcel" (p.79). It is ironic that adults code-switch with children, while punishing them, or while breast-feeding them; however, these same parents forbid their children to do likewise. Perhaps the reason is that although adults wish for their offspring to speak Standard English, the fact that they use Patwa for "emotional expressive speech", makes it difficult for them to notcode-switch from Standard English to Patwa when they feel emotional. Further, Paugh explains that despite adults' expectations for strict use of certain languages in the community, the older children simultaneously socialize the younger ones.

Finally, Paugh's (2005) study lends itself well to Vygotsky's socio-cultural theory of learning. With the older children showing the younger children how to carry on, as adults do with their language choices, they are indeed socializing them into a particular culture, which is, in reality their world, as they know it. This was all done through role-playing. Further, it is the parents themselves who are moulding the children to code-switch without even realizing it. It is, indeed, an example of Vygotsky's theory at work. Although the parents spoke about 
language restrictions, the way that they lived conveyed another message, and it is that message that is picked up by the children.

\section{Conclusion}

The purpose of this essay was to identify the sociolinguistic factors that influence a child's code-switching. The fact that children's code-switching has not been studied in depth in recent years, (Boeschoten \& Verhoeven Boeschoten, 1987; Cheng, 2003), and that researchers have found there are still countless monolinguals who feel that code-switching is inherently bad (Grosjean, 2010; Milroy \& Muysken, 1995; Pert \& Letts, 2006), makes the subject of this essay relevant. Essentially, this essay examined why children code-switch, by examining the factors that play an active role in moulding the child to code-switch, or in motivating him to use code-switching as a "contextualization tactic" in helping him convey his message (Ervin-Tripp \& Reyes, 2005, p. 90). Three significant factors as to why this happens were discussed.

The first factor that was addressed was parental strategies because very young children are influenced by the linguistic input that they receive by their parents. It has been shown that parental discourse strategies that parents choose to use directlycan either influence or discourage their child to code-switch. In fact, De Houwer (2009) contends that a parent's attitude on language mixing is linked to which strategy the parent decides to use in moulding his child's language development. Dopke's (1992) study illustrated that parental strategies can be categorized in terms of the amount of pressure a parent wants to exert on his child's language output. In her study, she shows that strategies that entail more constraint for the child to not mix the languages can produce different results than those which are considered more lenient. Likewise, Lanza (1997) categorizes parental strategies, emphasizing the kind of relationship a parent wants to create with his child when mixing languages: one that entails only one language, or one that includes two. Among her conclusions, Lanza states that parents who do not wish to have code-switching in their household greatly influence whether their child will code-switch. In fact, the actual strategy that parents choose to use in interacting with their child's mixed language is linked to what extent the child code-switches (Lanza, 1992a).

Juan-Garau and Perez-Vidal (2001) and Reyes (2004) remind us that a child's code-switching is not static; it continuously evolves as the child ages.Parental strategies that are used in a child's language development are equally not in a vacuum; they can change as the child grows older (Dopke, 1992). Further, Juan-Garau and PerezVidal claim that parental strategies are perhaps the most significant factors in explaining why a young child codeswitches.

The second reasonwhy children code-switch is language proficiency. Genesee, Nicoladis, and Paradis (1995) and Peterson (1988) both contend that proficiency and language mixing is interlinked. Quay (1995) has shown that young children can mix languages because of a lexical gap; the child may be simply lacking the essential vocabulary to complete his message. However, Fantini (1985) reminds us that young children may not systematically code-switch to their dominant language when they use their weaker language. Other factors such as parental strategies used by the parents might come into play (Fantini, 1985).

The proficiency of the addressee can also play a role in deciding if the child will code-switch. Children, both younger and older, are more likely to communicate with the addressee using a language that both are able to understand.

Further, Reyes (2004) states that child's proficiency is continuously changing as the child evolves in his two languages. In fact, as the child uses both languages, either in a monolingual or bilingual mode, his competence in using his two languages separately, or interchangingly will continuously improve "to maximize his gains"(MyersScotton, 1997, p. 31; Reyes, 2004); his code-switching will not primarily be due to difficulties with either a weaker language or a dominant language.

The final factor shown to influence code-switching in children was context. This final cause encompasses an array of different situations, which have been found to lead to code-switching. It was shown that a children's ability to choose the appropriate language to communicate with a stranger is developed very early. Moreover, extensions from the context such as topic was not found as important as participant, but they can also account for a child's code-switching (Fantini, 1985; McClure, 1977).

$\mathrm{Vu}$, et al. (2010) allowed us to observe how the context of a situation can impact a child to code-switch. Realignment and clarification switches were among those mentioned. Moreover, Fantini (1985) explains that children can, indeed use marked utterances to behave in a manner that the child's entourage is not accustomed to. 
Two functions known as "Appeal and / or Control" are examples of marked utterances that are employed by bilingual children.

Furthermore, the specific language that a child identifies with in any given situation has also been shown to lead a child to switch languages (Ervin-Tripp \& Reyes, 2005). In fact, these authors and others ((McClure, 1977; Paugh, 2005; Zentella, 1997) claim that social identity and its link with this linguistic phenomenon initially starts having an impact on language choice between the child and his parents. However, as the child becomes more active in his community, his code-switching normally emulates that of their entourage, and less of their parents.

Further research is needed to discover how other important sociolinguistic variables to influence a child's codeswitching. De Korsak (2008, p.5) claims that looking at how the child's own "agency" contributes to his codeswitching will be the new focal point of child code-switching in future research. She explains that "The role of the child is important in language socialization because eachdevelopmental path can be different depending on the types of practices the childengages in, what is expected of the child as a participant at different stages of life, and how the child engages-or fails to engage in the practice" (de Korsak, 2008, p. 46). Moreover, she suggests that children need to be seen as active players in their language development, changing, evolving as time passes. Zentella (1997, p.83) believes "individual differences in code-switching...constitute each child's unique way of being bilingual".

In closing, it is clear that de Korsak's (2008) plea for future research on child code-switching is valid. Although this review of the literature has examined some of the factors that influence children to code-switch, a more indepth review of how bilingual children use both of their languages in unique ways allowing them to "construct self presentations" (Myers-Scotton, 2002, p. 205) is naturally the next step.

\section{Acknowledgements:}

I would like to sincerely thank my thesis supervisor Kirsten Hummel for her patience and continuous support throughout the years that I needed to complete this masters. In fact, I was often overwhelmed or simply felt lost in the writing of this essay, and each time, Kirsten was always ready to offer feedback; this was so appreciated. Actually, this never-ending willingness to be there for her students was the key factor that allowed me to finish this Masters.

I would also like to thank Dr. Zita De Koninck for accepting to act as a reader in the evaluation of my essay. Moreover, Zita De Koninck was a professor whose ongoing encouragement to complete this Masters was invaluable. Not only has her courses on doing research contributed in significant ways to completing this Masters, but our spontaneous conversations in the hallways of the university have also been, where by she would always be both curious as to how I was doing on my Masters, and helpful in offering answers to any of my questions.

Other individuals who need to be thanked are indeed my family: Laurie-Ann and my three amazing daughters: Rosalie, Julia and Kamille. The time that I took to do this Masters was longer than I had anticipated; yet LaurieAnn supported me even though at times it was not easy. I thank her dearly for this act of kindness and courage. As for Rosalie, Julia, and Kamille, they need to be thanked as well for their unconditional love and endless support for Papa to complete his Masters. In reality, my family is the rock behind which I stand. They are precious and had they not chosen to support me as they did, I could not even have fathomed completing this Masters. I am forever grateful.

\section{References}

Arnberg, L. (1987). Raising children bilingually: The pre-school years. Clevedon: Multilingual Matters Ltd.

Auer, P. (1995). The pragmatics of code-switching: A sequential approach. One speaker, two languages: Crossdisciplinary perspectives on code-switching (pp. 115-135). Cambridge: Cambridge University Press.

Auer, P. (1998). Code-switching in conversation: Language, interaction and identity. London / New York: Routledge.

Backus, A. (2005). Codeswitching and language change: One thing leads to another? International Journal of Bilingualism,(9), 307-340.

Bader, Y. (1998). Lexical code-switching in the speech of an Arabic-English bilingual child. Journal of Applied Linguistics, 13(1), 3-17. 
Barron-Hauwaert, S. (2004). Language strategies for bilingual families: The one-parent-one-language approach. Clevedon: Multilingual Matters Ltd.

Blom, J., \& Gumperz, J. (Eds.). (1972). Social meaning in linguistic structure: Code-switching in Norway. Oxford: Basil Blackwell.

Bloomfield, L. (1933). Language. New York: Holt, Rinehart and Winston.

Boeschoten, E. H., \& Verhoeven, L. (1987). Language-mixing in children's speech: Dutch language use in Turkish discourse. Language Learning, 37(2), 119-215.

Bokhorst-Heng, W., \& Caleon, I. (2009). The language attitudes of bilingual youth in multilingual Singapore. Journal of Multilingual and Multicultural Development, 30(3), 235-251.

Bresnan, J. (Ed.). (2000). Optimal syntax. Oxford: : Oxford University Press.

Cantone, K. F. (2007). Code-switching in bilingual children. Dordrecht, The Netherlands: Springer.

Cantone, K. K., K; Müller, N; Schmitz, K. (2008). Rethinking language dominance in bilingual children. Linguistische Berichte, 215(8), 307-343.

Cashman, H. R. (2005). Identities at play: Language preference and group membership in bilingual talk in interaction. Journal of Pragmatics, 37(3), 301-315.

Cheng, K. K. Y. (2003). Code-switching for a purpose: Focus on pre-school Malaysian children. Multilingual Journal of Cross-Cultural and Interlanguage Communication, 22(1), 59-77.

Chomsky, N. (1972). Language and mind. New York: Harcourt Brace Jovanovich Inc.

Collins, W. M. (2005). Code-switching avoidance as a strategy for Maya (Mam). International Journal of American Linguistics, 71(3), 239-276.

Comeau, L., Genesee, F., \& Lapaquette, L. (2003). The modeling hypothesis and child bilingual code mixing. International Journal of Bilingualism, 7(2), 113.

Crain, S., \& Nakayama, M. (1987). Structure dependence in grammar formation. Language, 63(3), 522-543.

Croft, W. (2000). Explaining language change: An evolutionary approach. New York: Longman.

De Houwer, A. (1995). bilingual language acquisition. In P. Fletcher \& B. MacWhinney (Eds.), The handbook of child language (Vol. 1, pp. 219-250). Oxford, England: Blackwell Publishers.

De Houwer, A. (2005). Early bilingual acquisition: Focus on morphosyntax and the Separate Development Hypothesis. In J. Kroll \& A. de Groot (Eds.), The handbook of bilingualism. Oxford: Oxford University Press.

De Houwer, A. (2006). Bilingual language development: Early years. Encyclopedia of Language and Linguistics, $1,780-786$.

De Houwer, A. (2009). Bilingual first language acquisition. Bristol, UK: Multilingual Matters.

de Korsak, K. (2008). Fuzzy borders: Children's exploration of their language and identities. University of California, Davis.

Dopke, S. (1992). One parent one language: An interactional approach. Amsterdam: John Benjamins.

Eastman, C. M. (1990). Dissociation: A unified language-policy outcome for Kenya. International Journal of the Sociology of Language, 86(1), 69-86.

Eastman, C. M. (1992). Codeswitching as an urban language-contact phenomenon. Journal of Multilingual and Multicultural Development, 13(1), 1-17.

Ervin-Tripp, S., \& Reyes, I. (2005). Child codeswitching and adult content contrasts. International Journal of Bilingualism, 9(1), 85-102.

Fantini, A. (1985). Language acquisition of a bilingual child: A sociolinguistic perspective (to age 10). Clevedon: Multilingual Matters Ltd.

Gafaranga, J. (2001). Linguistic identities in talk-in-interaction: Order in bilingual conversation. Journal of Pragmatics, 33(12), 1901-1925.

Gamal, R. A. S. (2007). Code-switching patterns in infant bilingualism: A case study of an Egyptian ArabicEnglish-speaking four-year-old bilingual child. Dissertation Abstracts International, A: The Humanities and Social Sciences, 68(06).

Garcia, E. E. (1983). Early childhood bilingualism, with special reference to the Mexican-American child. Albuquerque, NM: University of New Mexico Press.

Gardner-Chloros, P. (2009). Code-switching. Cambridge: Cambridge University Press.

Genesee, F. (2001). Bilingual first language acquisition: Exploring the limits of the language faculty. Annual Review of Applied Linguistics, 21, 153-168. 
Genesee, F., Boivin, I., \& Nicoladis, E. (1996). Talking with strangers: A study of bilingual children's communicative competence. Applied Psycholinguistics, 17(04), 427-442.

Genesee, F., \& Nicoladis, E. (2006). Bilingual first language acquisition. In E. Hoff-Ginsberg \& M. Shatz (Eds.), Handbook of language development (pp. 324-342). Oxford, England: Blackwell.

Genesee, F., Nicoladis, E., \& Paradis, J. (1995). Language differentiation in early bilingual development. Journal of Child Language, 22(03), 611-631.

Genishi, C. (1976). Rules for code-switching in young Spanish-English speakers: An exploratory study of language socialization. Unpublished doctoral dissertation, University of California, Berkeley.

Giles, H., Bourhis, R. Y., \& Taylor, D. M. (1977). Towards a theory of language in ethnic group relations. In H. Giles (Ed.), Language, ethnicity and intergroup relations (pp. 307-348). London: Academic Press.

Goodz, N. (1989). Parental language mixing in bilingual families. Infant Mental Health Journal, 10, 25-44.

Grosjean, F. (1985). The bilingual as a competent but specific speaker-hearer. Journal of Multilingual and Multicultural Development, 6(6), 467-477.

Grosjean, F. (2008). Studying bilinguals: New York: Oxford University Press.

Grosjean, F. (2010). Bilingual: Life and reality. Cambridge: Harvard University Press.

Guasti, M. T. (2004). Language acquisition: The growth of grammar. Cambridge: The MIT Press.

Gumperz, J. (1976). The sociolinguistic significance of conversational code-switching. Papers on Language and Context: Working Papers no. 46.

Gumperz, J. (1982). Discourse strategies. Cambridge: Cambridge University Press.

Hamers, J., \& Blanc, M. (2000). Bilinguality and bilingualism. Cambridge: Cambridge University Press

Heredia, R. R., \& Altarriba, J. (2001). Bilingual language mixing: Why do bilinguals code-switch? Current Directions in Psychological Science, 10(5), 164-168.

Hopper, P. J., \& Thompson, S. A. (1980). Transitivity in grammar and discourse. Language, 56(2), 251-299.

Huerta, A. (1977). The acquisition of bilingualism: A code-switching approach. Sociolinguistic Working Papers No. 39.

Jorgensen, J. N. (1998). Children's acquisition of code-switching for power-wielding. In P. Auer (Ed.), Codeswitching in conversation: Language, interaction and identity (pp. 237-258). London / New York: Routledge.

Juan-Garau, M., \& Perez-Vidal, C. (2001). Mixing and pragmatic parental strategies in early bilingual acquisition. Journal of Child Language, 28(01), 59-86.

Köppe, R., \& Meisel, J. (1995). Code-switching in bilingual first language acquisition. In L. Milroy \& P. Muysken (Eds.), One speaker, two languages: Cross-disciplinary perspectives on code-switching (pp. 276-301). Cambridge: Cambridge University Press.

Kwan-Terry, A. (1992). Code-switching and code-mixing: The case of a child learning English and Chinese simultaneously. Journal of Multilingual and Multicultural Development, 13(3), 243-259.

Lanvers, U. (2001). Language alternation in infant bilinguals: A developmental approach to codeswitching. International Journal of Bilingualism, 5(4), 437-464.

Lanza, E. (1992a). The acquisition of two languages from birth: A case study. Journal of Child Language, 19(3), 717-722.

Lanza, E. (1992b). Can bilingual two-year-olds code-switch? Journal of Child Language, 19(03), 633-658.

Lanza, E. (1997). Language contact in bilingual two-year-olds and code-switching: Language encounters of a different kind? International Journal of Bilingualism, 1(2), 135-162.

Lanza, E. (2004). Language mixing in infant bilingualism: A sociolinguistic perspective: Oxford University Press, USA.

Lanza, E. (2009). Can bilingual two-year-olds code-switch? Journal of Child Language, 19(03), 633-658.

Leopold, W. (1949). Speech development of a bilingual child: A linguist's record: Vol. 3. Grammar and general problems in the first two years. Evanston, IL: Northwestern University Press.

McClure, E. (1977). Aspects of code-switching in the discourse of bilingual Mexican-American children. Urbana, Champaign, IL: University of Illinois Press.

McClure, E. (1981). Formal and functional aspects of the code-switched discourse of bilingual children. In R. P. Duran (Ed.), Latino language and communicative behavior (pp. 69-94). Norwood, NJ: Ablex.

McLaughlin, B. (1985). Second-language acquisition in childhood: School-age children (Vol. 2). Hillsdale NJ: Lawrence Erlbaum. 
Milroy, L., \& Muysken, P. (1995). One speaker, two languages. Cross-disciplinary perspectives on codeswitching. Cambridge: Cambridge University Press.

Myers-Scotton, C. (1993). Social motivations for code-switching: Evidence from Africa. Clarendon: Oxford.

Myers-Scotton, C. (1997). Code-switching. In F. Coulmas (Ed.), The Handbook of Sociolinguistics. (pp. 217237). Oxford: Blackwell Publishing Ltd.

Myers-Scotton, C. (2002). Contact linguistics: Bilingual encounters and grammatical out- comes. Oxford: Oxford University Press.

Myers-Scotton, C. (2006). Multiple voices: An introduction to bilingualism. Malden, MA: Blackwell Publishers.

Myers-Scotton, C., \& Bolonyai, A. (2001). Calculating speakers: Codeswitching in a rational choice model. Language in Society, 30(01), 1-28.

Myers-Scotton, C. M. (1982). The possibility of code-switching: Motivation for maintaining multilingualism. Anthropological Linguistics, 24(4), 432-444.

Nilep, C. (2006). Code switching in sociocultural linguistics. Colorado Research in Linguistics, 19(1), 1-22.

Ochs, E. (1988). Culture and language development: Language acquistion and language socialization in a Samoan village. Cambridge: Cambridge University Press.

Paradis, J., \& Nicoladis, E. (2007). The influence of dominance and sociolinguistic context on bilingual preschoolers' language choice. International Journal of Bilingual Education and Bilingualism, 10(3), 277297.

Paugh, A. L. (2005). Multilingual play: Children's code-switching, role play, and agency in Dominica, West Indies. Language in Society, 34(1), 63-86.

Pert, S., \& Letts, C. (2006). Codeswitching in Mirpuri speaking Pakistani heritage preschool children: Bilingual language acquisition. International Journal of Bilingualism, 10(3), 349-374.

Petersen, J. (1988). Word-internal code-switching constraints in a bilingual's child's grammar. Linguistics, 26, 479-493.

Poplack, S., Sankoff, D., \& Miller, C. (1988). Linguistics. The social correlates and linguistic processes of lexical borrowing and assimilation, 26(1), 47-104.

Quay, S. (1995). The bilingual lexicon: Implications for studies of language choice. Journal of Child Language, 22(02), 369-387.

Radford, A. (2004). Minimalist syntax: Exploring the structure of English. Cambridge: Cambridge University Press.

Reyes, I. (2004). Functions of code switching in schoolchildren's conversations. Bilingual Research Journal, 28, 77-98.

Romaine, S. (1995). Bilingualism (2nd ed.). Oxford: Blackwell Publishers.

Saunders, G. (1982). Bilingual children: Guidance for the family. Clevedon, Avon: Multilingual Matters Ltd.

Saunders, G. (1988). Bilingual children: From birth to teens. Philadelphia, PA: Multilingual Matters Ltd.

Shin, S. J., \& Milroy, L. (2000). Conversational codeswitching among Korean-English bilingual children. International Journal of Bilingualism, 4, 351-383

Song, J. (2007). Language ideologies and identity: Korean children's language socialization in a bilingual setting. Ph.D dissertation, The Ohio State University, Ohio, Columbus.

Sridhar, S., \& Sridhar, K. (1980). The syntax and psycholinguistics of bilingual code mixing. Canadian Journal of Psychology, 34, 407-416.

Tabouret-Keller, A. (1969). Le bilinguisme de l'enfant avant six ans: Étude en milieu alsacien Thèse lettres. Estraburgo: Université de Strasbourg.

Taeschner, T. (1983). The sun is feminine: A study on language acquisition in bilingual children: Springer-Verlag Berlin.

Tokuhama-Espinosa, T. (2003). The multilingual mind: Issues discussed by, for, and about people living with many languages. Westport, CT: Praeger Publishers.

Valdés, G. (1978). Code-switching as a deliberate verbal strategy: A microanalysis of direct and indirect requests among bilingual Chicano speakers. In R. P. Duran (Ed.), Latino discourse and communicative behavior (pp. 95-108). Norwood, NJ: Ablex.

Vihman, M. M. (1985). Language differentiation by the bilingual infant. Journal of Child Language, 12(02), 297324.

Volterra, V., \& Taeschner, T. (1978). The acquisition and development of language by bilingual children. Journal of Child Language, 5, 311-326. 
Vu, J., Bailey, A., \& Howes, C. (2010). Early cases of code-switching in Mexican-heritage children: Linguistic and sociopragmatic considerations. Bilingual Research Journal, 33(2), 200-219.

Vygotsky, L. S. (1974). Thought and language. Cambridge. MA: MIT Press.

Wei, L. (1998). The 'why' and 'how' questions in the analysis of conversational code-switching Code-switching in conversation: Language, interaction and identity (pp. 156-176). London / New York: Routledge.

Wolck, W. (1987). Types of natural bilingual behavior: A review and revision. Bilingual Review, 14(3), 3-16.

Zentella, A. C. (1981). Tà bien, you could answer me en cualquier idioma: Puerto Rican codeswitching in bilingual classrooms. Latino Language and Communicative Behavior, 6, 109-132.

Zentella, A. C. (1997). Growing up bilingual: Puerto Rican children in New York. New York: Basil Blackwell.

Appendix

Stages of language development (From Age 0 to 7 years)

- As a newborn baby the child is aware of two languages and may well have heard themin the womb too. He or she is sensitive to his direct carers' language use in the first few months as a survival technique-he must respond to his carers for them to feed and look after him.

- From three to six months onward a linguistic rapport is set up between mother and child, with the baby preferring her voice and being soothed by it. He or she will smile, gurgle and babble in response to being talked to or sung to. The father's voice will also be recognised and reacted to positively.

- As the child reaches its first year the languages sensitivity is reduced and a wider outlook on life appears as the baby sits, crawls and walks around exploring the world. Objects and concepts can be labelled and talked about at this stage. First words appear, usually close carers and objects within reach such as Mama, Papa, spoon, cup, teddy, etc.

- Around age two, the child becomes aware that communication can take place in two languages. He or she realises that some people speak different languages, or some speak only one language. The toddler realises that objects may have two different labels. The child may mix languages in an attempt to communicate and lacking enough words he or she may substitute or borrow words across his two languages.

- The child then becomes aware of language differentiation and that each language is different (i.e. Finnish is different to English) around age two to three. He or she will try to respond in the appropriate language to the right person. The child still mixes sometimes as a way of communicating or when with bilingual speakers who understand both languages.

- At around age four the child then gains more social awareness; talking the right language to speaker. He or she begins to follow the social norms of the culture in different format settings (at nursery or school, in shops or with strangers etc.) or informal settings (playing with other children, with family and friends, neighbours etc.). Mixed language use fades out with monolingual speakers as he or she realises it is simply not appropriate or accepted.

- As school starts the child begins to grasp the use of the language in the wider society outside of his or her family and friends. He or she will make an effort to choose the appropriate social form with prior knowledge. The school child understands clearly the role of formal/informal language. He or she may refer to the language by name, such as "I speak French" and explain to people why he or she is speaking a certain language.

- Finally, at about age six or seven the child reaches a stage where he is capable of switching languages according to speaker, topic, setting, language hierarchy and the social norms. This takes some time to reach and requires fluency in both languages and familiarity with social etiquette gained over previous years and empathy with another speaker in which language is understood and can or cannot be used. He or she begins to read and write and explore the world through text and writing.(Barron-Hauwaert, 2004, pp. 30-31) 